Collection Building 27:1, 2008 (Emerald). Accepted, to be published Jan. 25, 2008.

This is a post-publication, deposited copy of: Monica Berger, (2008) "Scholarly monographs on rock music: a bibliographic essay", Collection Building, Vol. 27 Iss: 1, pp.4 - 13, DOI 10.1108/01604950810846189, copyright Emerald Group Publishing.

\title{
Scholarly monographs on rock music: a bibliographic essay Monica Berger
}

Assistant Professor, Technical Services and Electronic Resources Librarian, New York City College of Technology, CUNY, Brooklyn, NY, USA.

\begin{abstract}
Purpose This article is an overview of scholarly monographs on rock music from 1980 to the present. It provides an overview to the literature for practical purposes of collections development as well as giving the reader insight into key issues and trends related to a interdisciplinary topic that attracts scholars from many disciplines in the humanities and social sciences.
\end{abstract}

Design/methodology/approach This bibliographic essay, focusing on works related to American culture and of a general nature, includes an overview and historical background; a discussion of how music and ethnomusiciological scholars approach the topic; geographic approaches; literature on four key icons (Elvis, Dylan, Springsteen, and Madonna); American studies; subcultures and genres; other methodologies; and concludes by discussing notable recent works.

Findings The scholarly literature on rock incorporates a wide variety of approaches and methodologies. Many music-related scholars appropriate methodology from other disciplines and some non-music-related scholars use the formalistic analysis of music scholars. Authenticity is a major theme in the literature on rock.

Originality/value This essay covers the widest range of monographs on the topic, providing insight into not only the key scholars but also the diversity of approaches to the topic. The historical approach to the literature gives the reader a sense of how the academic discourse on rock has evolved. This essay is of interest to librarians, scholars of rock music, and others concerned with how American scholarship in the humanities and the social sciences has grown since the advent of cultural studies.

Keywords Rock music, Scholarly monographs, Methodology, Bibliographic essay

Paper type Literature review

\section{Introduction}

This bibliographic essay addresses how the academic discourse on rock has evolved and focuses on monographs that address rock in American culture or of a general nature. 
Collection Building 27:1, 2008 (Emerald). Accepted, to be published Jan. 25, 2008.

Writing on rock can be found in disciplines ranging from psychology to American studies to geography. Scholarly work on rock music uses a variety of methods and is often interdisciplinary in nature. Elvis may be everywhere but so is rock music. No one individual or discipline owns the scholarly discourse on rock. There are many players and specific points of convergence. In designing a bibliography or bibliographic essay, the author can divide the content in a variety of ways. Earlier incarnations of this work were organized by academic discipline and methodology but the author has chosen to organize this essay around the themes of specific performers, genres, and subcultures, as well as theories, methods and disciplines. By focusing on topics over methods, it is easier to see the broad arc of change in scholarly approach and method.

After providing an overview of the author's parameters and methods and a broad historic overview of the topic, the bibliographic essay addresses issues of methodology. The formalist approach of musicology and related fields contribute to a core debate in rock methodology: can music be discussed in a meaningful manner without formal analysis? Accordingly, this essay will open with a discussion of more recent work in musicology or, as the author calls it, the "new musicology." The musicology section will be followed by discussions of innovative work in ethnomusicology, and the related field of ethnography, and the related topic of spaces and places. This part of the essay is followed by literature overviews on the four dominant personalities of rock, Elvis, Dylan, Springsteen and Madonna. Moving from the cult of personality to the consumers of rock music, the next section reviews writing on fan cultures and subcultures as well as other methodologies such as media studies. This essay will conclude by looking at some cutting edge works on the academic rock discourse.

This article is based on the author's master's thesis in American Studies, an annotated bibliography of scholarly monographs from 1980 to the present on rock music focusing on methodology. To bring it under the umbrella of American studies, and to provide needed limits, materials were limited to works that looked at rock music in American culture or works that had no specific geographic base. Accordingly, only a limited number of works relating to the Beatles were included. Works that were purely musicological were eliminated because they have no socio-cultural referent. Quasischolarly but influential authors such as Greil Marcus were included.

Defining rock is no easy matter. The New Grove Dictionary of Music and Musicians defines rock as "a term used to denote a particular category of pop music." Subgenres of rock music include psychedelic rock, punk, rockabilly, Christian rock, progressive rock, heavy metal, and rock and roll. A somewhat broad definition of rock was selected that includes some pop music such as Madonna. However, books on nonrock or pop genres including blues, funk, rap, hip-hop, jazz, disco, techno, bluegrass, country, and folk were excluded. However, some books on folk are included if they discussed the Folk Revival in the United States that include Bob Dylan and other performers that crossed-over into the pop and rock world.

This bibliographic essay, by limiting content to monographs, eliminates a significant body of scholarship. A monograph, for the purpose of this bibliographic essay, 
Collection Building 27:1, 2008 (Emerald). Accepted, to be published Jan. 25, 2008.

is defined as a book by one or two authors and not as a book-length collection of essays by different authors. Monographs are not representative of the overall body of work in any discipline but are representative of core texts by the major scholars on a topic. The tip of the iceberg, monographs are less in number but likely more broadly influential to a wider reading audience in a broader variety of academic specializations. By limiting this essay to monographs, it is easier to ascertain the academic superstars as well as the academic specializations of authors.

The interdisciplinary nature of the literature can be daunting. Searching OCLC's WorldCat and some other key online catalogs by subject is far less complex than searching the periodical literature. The indexing of academic journal literature on popular music is a complex issue since some online, specialized indexes on music are poorly designed for the purposes of this investigation and may not index the substantial body of literature outside of musicology or ethnomusicology. General and humanities indexes are dauntingly broad. The journal Popular Music and the International Association for the Studies of Popular Music are both immensely influential but skew, to some extent, towards musicology and ethnomusicology. In order to provide the best overview of all scholarship on rock in all disciplines, the monographic literature seems the most accessible format to analyze. Scholars may be familiar with key influential articles but not the overall and highly variable body of writing on rock.

\section{Historical overview}

The year of 1980 was selected as the earliest possible date to analyze materials for this essay. The following historical overview will help explain the author's choice to not discuss American writing on rock prior to 1980. Ray Browne, in 1969, at Bowling Green State University, established popular cultural studies as an offshoot of American studies. Some early popular culture scholarship seems more factual and documentary than theoretical. Certainly, early writing on rock is very "straight": authors were more concerned with gathering historical details than untangling the complex and circular dynamic between musical object, reception by audiences and fans, socio-historical circumstance, and the role of the music industry and media.

Charlie Gillett's 1970 The Sound of the City : The Rise of Rock and Roll and Carl Belz's 1969 Story of Rock are the first significant monographs on the socio-history of rock music. More recently in its third edition, Sound of the City, informed by sociology, probes the origins and early history of rock music and touches on issues of race and the collision of Northern urban music and Southern rural music. Betsy Bowden's 1982 Performed Literature : Words and Music by Bob Dylan, is indicative of another early strain of rock scholarship: the hermeneutic study. Bowden, an English professor, used literary analysis and close readings of lyrics and performance images and does not draw broader conclusions. Herbert London's 1984 Closing the Circle : A Cultural History of the Rock Revolution relates rock to American history but is based on positivistic ideas of history that are long outmoded. 
Collection Building 27:1, 2008 (Emerald). Accepted, to be published Jan. 25, 2008.

By this time, the British Birmingham School method of cultural studies had taken root in England as a new approach to analyze culture, especially popular culture. Simon Frith is the most representative writer emerging from this period and continues to be immensely influential. Frith's work always considers the dynamic between music and the listener. His 1978 essay, written with Angela McRobbie, "Rock and sexuality," is the first theoretical discussion of the relationship between rock and gender. Andy Bennett's 2002 article "Researching youth culture and popular music : a methodological critique" is a useful history of British writing on music-related youth cultures.

The publication of Janice Radway's Reading the Romance in 1984, a study of readers of Harlequin-style romance novels, was significant in the history of American pop culture scholarship: employing cultural studies, it placed emphasis on how individuals use popular culture and it also employed social sciences methods such as surveys. The writings of George Lipsitz on popular music in the 1980s were groundbreaking as well. Lipsitz continues to consider how social class, ethnicity and race play into political and cultural power and control and how popular music does more than mirror these tensions: it can be a functional tool of the people.

Cultural studies slowly infiltrated American academia and by the late 1980s, the hermeneutic strategies of post-structuralism grew tiresome: the time was ripe for a theory that emphasized everyday life and that considered the consumers of culture and the politics of cultural production. Cultural studies repositioned popular culture as a form of resistance to hegemony (Harrington and Bielby, p. 4-5). Simultaneously, new interdisciplinary academic discourses arose including ethnic studies, women's studies, more recently queer and star studies, and so on. These areas have grown increasingly complex and the advent of the new musicology of the early 1990s further complicates this history.

\section{The new musicology}

Is there a turf war between music scholars and scholars from outside the field of music? Some musicologists and theorists privilege formalist readings. Perhaps this contestation is an issue of "chops": music scholars are grounded in very specific analytical knowledge and skills that can generate a certain kind of close reading unavailable to other scholars. It is the author's impression that by the late 1990s, scholarship on popular music in the musicology and music theory communities reached a critical mass and the discourse within that community became more explicit. The International Association for the Study of Popular Music (IASPM)'s 1999 "Roundtable : the future of popular music studies," in the Journal of Popular Music Studies, reflects the complex responses to popular music in the music community. Over the last ten years, however, most contemporary musicologists and theorists approach popular music by synthesizing formal approaches with broader, external analysis of the object at hand, and, often utilize interdisciplinary methods. 
Collection Building 27:1, 2008 (Emerald). Accepted, to be published Jan. 25, 2008.

John Covach, a professor of music theory, in a 1997 essay, finds a disconnection between music theory focused on European Art music and popular music scholars more centered in cultural studies (p. 76). Covach feels music theorists would benefit from studying popular music and popular music scholars would benefit from employing music theory (p. 76). However, claiming turf for the music formalists, when discussing Frith's criticism of Meller's musicological approach to the Beatles \& Dylan, Covach notes that

writers in popular music scholarship sometimes set up the theorist or musicologist as a straw man, as a caricature that serves as a foil to their own ideas. It is as if these writers were against the idea of theorists examining popular music as a matter of principle (p. 83).

Musicologists started writing on popular music and incorporating theory into their scholarship beginning around 1990, about five years after social sciences and the humanities scholars took to using theory to discuss rock. Perhaps the first was Richard Middleton. His 1990 Studying Popular Music crosses over into considerations of the social aspects of popular music. This book is particularly valuable in that is details how musicology has approached popular music and relates issues in musicology to other disciplines such as cultural studies as well as folklore studies, anthropology, structuralism, sociology, semiotics, aesthetics and psychoanalysis. The issue of what makes music popular is a major theme.

The husband and wife team of Susan McClary and Robert Walser represented the vanguard. Susan McClary's 1991 book Feminine Endings was chiefly about non-popular music but featured chapters on Laurie Anderson and Madonna and other performers and employed close readings. Robert Walser's groundbreaking 1993 Running with the Devil : Power, Gender, and Madness in Heavy Metal Music continues to be the most comprehensive monograph on heavy metal. Walser synthesizes close readings of the music (including transcription) with methods derived from cultural studies, including ethnography of metal fans and musicians.

Music as Social Text is a seminal 1991 crossover work by the British musicologist John Shepherd. Addressing musicologists, Shepherd seeks to relate the relationship between taste and self-definition in popular music to analysis of musical texts (meaning rhythm, timbre, pitch, etc.). Much of the book is a response to theory about music not only from the cultural studies camp but also influenced by Ong and McLuhan. David Schwarz is a musicologist was has been inspired by the new musicology of Susan McClary. His 1997 Listening Subjects: Music, Psychoanalysis, Culture is influenced by the theories of Slavoj Zizek. Schwarz combines Lacanian psychoanalysis, history, Marxism and popular culture, and close musical readings to discuss the relationship between music and the body. Susan Fast's fascinating In the Houses of the Holy : Led Zeppelin and the Power of Rock Music (2001) employs close readings of the music (including transcription) but also utilizes gender theory and star studies theory. Fast employed surveys to gather her "data" on the fans, includes detailed observations of concert s performances (often lacking in most scholarly studies) and provides performance photographs and fan drawings. Women Led Zeppelin fans are asked by Fast 
Collection Building 27:1, 2008 (Emerald). Accepted, to be published Jan. 25, 2008.

to consider how, as heterosexual women, their gender and sexuality are informed by Zeppelin's "cock rock."

This new musicology is employed by other academics. For example, John Mowitt, cultural studies, employed musicological methods to great success in his Percussion : Drumming, Beating, Striking (2002) which examines rock drumming and its meaning. The author's methodology is broadly theoretical and uses cultural studies as well as psychoanalytical theory. The body and the skin provide a context for drumming. Focus includes not only the sounds created but also the drummer in relation to the drums.

Use of theory by musicologists in the monographic discourse of popular music became significant by the late 1990s (the periodical literature used this mixed methodology earlier than the monographic literature) and there is a steady production of new titles that synthesize musicological analysis with other methodologies. Ethnomusicologists are also using innovative methodologies that may or may not include close readings of music.

\section{Ethnomusiciological/ethnographic techniques and personal narratives}

To some extent, all works using ethnographic techniques are distinctive to spaces and places but since ethnomusicology is a distinctive discipline related to musicology, ethnomusicology and ethnography will be considered distinctly.

The first work to use ethnography is H. Stith Bennett's 1980 study of the sociology of rock musicians, On Becoming a Rock Musician. Bennett, a rock musician, would join local Colorado bands and then observe them. Writing from the inside, Maureen Mahon, an anthropologist, becomes part of the Black Rock Coalition. Her 1997 The Black Rock Coalition and the Cultural Politics of Race in the United States explores the relationship between race and rock. Another ethnomusicology monograph of note is Harris Berger's 1999 Metal, Rock, and Jazz Perception and the Phenomenology of Musical Experience. He synthesizes close musical analysis, including transcription, with interviews of musicians and listeners based in northeastern Ohio from four specific music scenes: commercial hard rock and African American jazz in Cleveland and death metal and European American jazz in Akron. One of the author's favorite works using ethnography is Mimi Schippers' 2002 Rockin' Out of the Box : Gender Maneuvering in Alternative Hard Rock. Schippers uses the idea of gender maneuvering strategies to express the mutability and performativity of gender in the post-punk alternative music culture. Schippers writes in the first person. William Echard in Neil Young and the Poetics of Energy (2005) looks at music critics on Neil Young, the discourse of Neil Young fans based on the Internet and does close readings of Young's recordings. He also notes a lack of discussion related to gender on Young and accordingly explores this issue.

\section{Spaces and places: geographies}


Collection Building 27:1, 2008 (Emerald). Accepted, to be published Jan. 25, 2008.

Some scholars focus on specific physical spaces and places. A space can be also be a subculture. However, subcultures will be addressed later in this essay when discussing cultural studies. University presses often have a local or regional focus in their publications and this trend applies to books on popular music as well.

A vanguard book about the Beatles and geography, Robert Kruse's $2005 \mathrm{~A}$ Cultural Geography of the Beatles, uses a form of cultural geography to challenge Kruse's own disciplinary tradition. Austin, Texas is the subject of Americanist Barry Shank's highly readable Dissonant Identities : The Rock'n'Roll Scene in Austin, Texas (1994). Shank uses a critical cultural studies ethnographic method to explore the relationship between identity construction of musicians and fans and physical place. Tracy Laird's Louisiana Hayride (2005) looks at the influential radio program that set the stage for the birth of rock and roll. She uses a classic American studies approach in synthesis with her field of ethnomusicology. Tim White's social history, The Nearest Faraway Place : Brian Wilson, the Beach Boys, and the Southern California Experience (1994) uses Brian Wilson and the Beach Boys to explore a specific time and place.

\section{Cult of personality: rock scholarship of pop icons}

Academic monographic writing on rock can be reduced to the "big three": Elvis, Dylan, and Springsteen. Madonna is a pop icon and no rocker. However, the academic industry of Madonna studies is so staggering that it would remiss to not address her. The author will also briefly touch on the Beatles. The consideration of popular music icons, raises the issue of whether popular culture must be popular to merit discussion. Other questions raised are how truly influential are Springsteen and Madonna in the history of popular music and in contemporary music? Are these four icons giant blank screens that allow for cultural projection and that provide a space for scholars to ponder big issues? Is academic writing viral? Why is there only one book on Neil Young and one book on Led Zeppelin and dozens on Dylan?

\section{Elvis is everywhere}

And indeed, Elvis is everywhere. George Plasketes has written a couple of nontheoretical and fun Elvis books about Elvis as icon, Images of Elvis Presley in American Culture (1997) and, with R. Serge Denisoff, True Disbelievers : The Elvis Contagion (1995) which probes the "Elvis faked his death" myth. Almost one out of every ten Southerners believes that Elvis is alive. Elvis' Southern, hillbilly heritage and differing representations of that heritage provide the focus for Susan Doll's, Understanding Elvis : Southern Roots vs. Star Image (1998). Elvis fandom is explored through extensive interviews and firsthand observations of Elvis places in Americanist Erika Doss's Elvis Culture : Fans, Faith, \& Image (1998). All of these books employ some methodology from star studies. Focusing largely on Elvis places, Karal Ann Marling's Graceland: Going Home with Elvis (1996) has a visual focus and features poetic prose. For a good summation of the complexity of the academic discourse on "why Elvis?" consider Gilbert B. Rodman's Elvis after Elvis : The Posthumous Career of a Living Legend (1996). 
Collection Building 27:1, 2008 (Emerald). Accepted, to be published Jan. 25, 2008.

Lastly, Greil Marcus' Dead Elvis has reproduces myriad images of Elvis mutations, e.g. Gary Panther's Elvis Zombie. The visual documentation and orientation of this book makes it noteworthy. The outstanding American studies book on Elvis is Michael Bertrand's Race, Rock and Elvis. (2000).With a heavy emphasis on historical research, Bertrand examines rock and roll music as an expression and cause of social change in Southern history from 1945 to 1960, a period of great upheaval including the nascent civil rights movement and Southern urbanization. Before considering Dylan, the author of this essay will discuss a few outstanding American studies works.

\section{American studies and American social history}

What does popular music say about the myth of "America"? Americanist Timothy Scheurer's Born in the U.S.A. : The Myth of America in Popular Music from Colonial Times to the Present (1991) is influenced by anthropologist Clifford Geertz and Scheurer explores whether popular music is hegemonic (patriotic songs) or counterhegemonic (slave songs and labor songs) or both?

Walt Whitman begat Woody Guthrie and Harry Smith's Anthology of American Folk Music begat Bob Dylan's weird old America which begat Bruce Springsteen. Perhaps the first author to draw some of these connections was Greil Marcus in his highly influential but non-scholarly 1975 Mystery Train. For a more academic approach, see Bryan Garman's excellent A Race of Singers : Whitman's Working-Class Hero from Guthrie to Springsteen (2000).He considers Woody Guthrie's influence on Pete Seeger, Bob Dylan and Bruce Springsteen and the subtexts of heterosexuality and whiteness in this lineage.

\section{That weird old America: Dylanology}

As discussed previously, early writings on Dylan are, to generalize, literary-oriented, e.g. Herdman's Voice Without Restraint_(1982) and Bowden's Performed Literature. Interestingly, one of the recent books to gain attention by the broader media also employs this approach and is by poet and academic Christopher Ricks. His 2004 Dylan's Visions of Sin uses classical literary tropes.

An outstanding early book on Dylan is by musicologist Wilfrid Mellers and is typical of his work in that it is readable without compromising on depth. His A Darker Shade of Pale : A Backdrop to Bob Dylan (1985) utilizes an orthodox American studies methodology to analyze Dylan and his music as representative of his times and to relate Dylan to broader themes in American culture including the myth of an Edenic America and the idea of folk culture. Mystery Train was published in 1975 and Marcus continued to explore Dylan in subsequent works including his 1997 Invisible Republic : Bob Dylan's Basement Tapes and his 2005 exploration of "Like a rolling stone," (Like a Rolling Stone : Bob Dylan at the Crossroads). Exploring Dylan's historical precedents, a section of Benjamin Filene's Romancing the Folk: Public Memory and American Vernacular Music in the Twentieth Century (2000) is "pure" American studies and 
Collection Building 27:1, 2008 (Emerald). Accepted, to be published Jan. 25, 2008.

connects Dylan to Pete Seeger and issues of social class and authenticity are considered. Considerations of social class and authenticity relate to this essay's next "star": Bruce Springsteen.

\section{Born to write: scholars on Springsteen}

Scholars on Springsteen focus on Springsteen as emblematic of American culture. They also write at length about Springsteen in terms of his fan culture, and, Springsteen as embodying the intersection of authenticity, class and gender. An excellent representation of an orthodox American studies approach, Jim Cullen's Bruce Springsteen : Born in the U.S.A. and the American Tradition (1997) traces Bruce Springsteen as a champion of the common man to such predecessors as Ralph Waldo Emerson, John Dewey, Mark Twain, and Walt Whitman. Cullen looks at Springsteen's depictions of manhood, a topic considered by other theorists and critics. Daniel Cavicchi's Tramps Like Us : Music \& Meaning Among Springsteen Fans (1998) uses a blend of methods, primarily ethnography but star studies as well. Cavicchi rejects the view that fandom is counterhegemonic. Ray Pratt in his Rhythm and Resistance : Explorations in the Political Uses of Popular Music (1990) provides a more complex argument stating that the Springsteen phenomenon symbolic of all the "power and contradictions of contemporary popular culture" (176). Pratt explores rock authenticity as a type of false consciousness and an expression of masculinity.

\section{Madonnarama}

There is a considerable body of academic writing on Madonna and postmodernity theory is often employed. The chameleon-like qualities of Madonna's persona, as well as her explicit playfulness with gender and sexuality, make her an ideal subject. GeorgesClaude Guilbert's Madonna as Postmodern Myth (2002) draws from a broad palette of theory: postmodernism, gender theory on performativity (Judith Butler), camp, and colonialism. Karlene Faith's Madonna, Bawdy \& Soul (1997) focuses on Madonna's reception and her fan culture and is informed by feminist as well as cultural studies theory. Faith devotes an entire chapter to comparing Madonna to Michel Foucault. The parallels are fascinating. A challenging and highly theoretical overview of the academic discourse on Madonna is a feature of Robert Miklitsch's From Hegel to Madonna (1998). Miklitsch discusses Madonna scholars including E. Ann Kaplan, Lisa Lewis, John Fiske, Kathy Schwichtenberg, Susan Bordo, Cindy Patton, Simon Frith, bell hooks, and Kobena Mercer.

\section{Feminist and gender theory}

Before there was theory, there was history. Wilfrid Mellers' Angels of the Night : Popular Female Singers of Our Time (1986) is representative of this tendency in American academic writing pre-theory. During the heyday of MTV, there was a plethora 
Collection Building 27:1, 2008 (Emerald). Accepted, to be published Jan. 25, 2008.

of feminist writing on music videos and Lisa Lewis's 1990 Gender Politics and MTV: Voicing The Difference, is typical in its consideration of music videos as misogynistic as well as helpful to female musicians.

In response to Simon Frith's work, Simon Reynolds and Joy Press's 1995 The Sex Revolts : Gender, Rebellion, and Rock ' $n$ ' Roll is one of the first book-length works to seriously consider the issues of gender and sexuality in rock and roll and it continues to be influential. The authors are journalists but the book is informed by psychoanalytic theory. Representative of the theoretical bricolage of contemporary work is Neil Nehring's Popular Music, Gender, and Postmodernism : Anger is an Energy (1997) which will be discussed later. Yet important historical work continues in academe: Lisa Rhodes in her Electric Ladyland (2005) explores the connection between the feminist movement and 1960s and 1970s rock through secondary figures in the history of the music: women rock journalists and famous female groupies. Gender is no longer equated with women: an example is Peter Lehman's 2003 Roy Orbison. Lehman, close reads Orbison's voice, lyrics, persona, and performance style, and sees a connection between gender and masculinity, sexuality, and race. Burns and Lafrance's 2002 Disruptive Divas : Feminism, Identity, and Popular Music is co-written by a musicologist and a feminist scholar and uses four specific female musicians to explore how these musicians negotiate their identity, a very contemporary concern, through their music. Taking a more intimate approach, Carson, Lewis and Shaw in Girls Rock! (2004) cover the history of women in rock but also address the personal experiences of female rock musicians. Sheila Whiteley is probably the leading scholar on gender and popular music. She is a musicologist and her writings employ a variety of methods and theories. Her solo monograph is Women and Popular Music: Sexuality, Identity and Subjectivity (2000). Whiteley has written some brilliant articles on the Beatles.

\section{A little Beatles}

An exotic yet readable application of theory is Henry Sullivan's 1995 The Beatles with Lacan : Rock ' $n$ ' Roll as Requiem for the Modern Age. Many may be familiar with historian Jon Weiner's two books on Lennon's difficult relationship with American politics and the Nixon administration. Perhaps not as well known, Anthony Elliott's heavy-going 1999 work on Lennon, The Mourning of John Lennon employs star studies (see below for more explication on the field of star studies) and psychoanalytical theory. There is extensive academic writing on the Beatles but not that much monographic writing considering their role in American culture.

\section{Cultural studies, fan cultures, subcultures}

Star studies grew out of cultural studies. The father of cultural studies for popular music, as briefly discussed in this article's introduction, is Simon Frith. His 1988 collection Music for Pleasure includes some substantial pieces considering the relationship between the unpredictability of technology and popular music. Frith believes subcultural theory 
Collection Building 27:1, 2008 (Emerald). Accepted, to be published Jan. 25, 2008.

has contributed to the idea of authenticity in rock tied to urban working class and/or "street" culture. However, Frith considers rock to be more of a suburban phenomenon. He also debunks the idea of rock authenticity as intrinsically masculine and heterosexual. His 1996 Performing Rites : On the Value of Popular Music applies Pierre Bourdieu's ideas of cultural capital to revisit the topic of taste and aesthetics and value judgments on popular music, long banished from the academy. Exploring the connections between New York glam, proto-punk, and world of the avant-garde, Van M. Cagle's Reconstructing Pop/Subculture : Art, Rock, and Andy Warhol (1995) is important in the body of rock scholarship but also probe the ironies and contradictions inherent in this period of rock music history. Authenticity was turned on its head as performers created otherworldly personas and played with ambiguous sexuality. More recently, Roy Shuker's second edition of Understanding Popular Music (2001) provides an excellent overview of the history of the use of cultural studies for analysis of rock music and notes a maturing of the discourse in the late 1990s. Star studies is a more recent academic area that employs many ideas from cultural studies and focuses on the performer's "star story" and "star image." Philip Auslander's Performing Glam Rock (2006), follows in Cagle's footsteps but places more emphasis on visual representation, particularly performance style.

\section{From Jesus to the Devil: two subcultures, Christian rock and metal}

There is a small but substantial body of academic writing on Christian rock written by academics at Christian colleges, religion studies scholars and other disciplines. The core academic monograph on Christian rock, Apostles of Rock (1999) is written by two communications scholars, Howard and Streck. It covers all aspects of this genre. Robin Sylvan's Traces of the Spirit (2002) is a fascinating book on the connection between religion and popular music that addresses a variety of subcultures including Deadheads and metal culture. Sylvan postulates that the religious impulse in modern life, for many, has migrated from organized religion to popular music

Perusing theses and some journal literature, the author noticed that heavy metal as social pathology was a popular topic in the 1980s into the 1990s. Deena Weinstein is the major scholar on metal. Her 1990 Heavy Metal, revised in 2000, and originally published in 1990, is the first full-length scholarly study of the sociological aspects of heavy metal, preceding Walser's Running with the Devil. Weinstein, as a sociologist, utilizes surveys, firsthand observations and interviews but brings in the music itself, the fans and fan literature as well as metal's portrayal in the media. The other substantial monograph on metal was written in 1996 by psychology professor Jeffrey Arnett. Although Arnett comes from the "deviance and social pathology" viewpoint, the author is remarkably empathic and employs first hand observations of concerts as well as interviews.

\section{Punk and Riot Grrrl}

Brit Dave Laing's 1985 One Chord Wonders, employing semiotics, may have been the first major scholarly text on punk (specifically as a late 1970s musical movement). The 
Collection Building 27:1, 2008 (Emerald). Accepted, to be published Jan. 25, 2008.

core of the text considers the meaning of punk rock. The first American scholarly book on punk is Tricia Henry's 1989, Break All Rules! Focusing on music emanating from New York City, Henry's extensive use of primary sources, including fanzines and fan interviews, enrich the book. Henry, like Greil Marcus, connects punk to other avantgardes. Recent monographs on punk include Malott's and Pena's Punk Rocker's Revolution (2003), Stacy Thompson's Punk Productions (2004), both of which employ cultural studies methods, and sociologist Ross Haenfler's study of straight edge (2006). These contemporary authors write as "insiders" of their subject subcultures. The body of scholarship on Riot Grrrl and girl culture is largely book chapters and articles. The sole monograph is by Riot Grrrl scholar Mary Celeste Kearney. Her Girls Make Media (2006) emphasizes visual and print culture, but has a broader focus that includes music.

\section{Other methodologies}

\section{Freudian theory, postmodernity, ethnicity}

"Pure" Freudian, as well as Marxist theory, is employed in Ben Watson's quirky book on Frank Zappa, The Negative Dialectics of Poodle Play (1995). The author of this essay has touched on postmodernity in this article's section on Madonna. Another major employment of postmodernity theory was in the analysis of music videos during the late 1980s and early 1990s. Was this a reflection of the zeitgeist or intrinsic to the multimedia nature of music videos? The original scholar to address popular music using postmodernity as a central theory, E. Ann Kaplan, wrote her book on MTV in 1987. Andrew Goodwin followed in similar territory with his 1992 Dancing in the Distraction Factory.

Issues of race are touched upon in many of the books discussed in this paper. A good example of a sophisticated discussion of race, specifically on blackness and whiteness, is Steve Waksman's Instruments of Desire which the author of this essay will discuss in this article's conclusion. Two studies relating rock and ethnicity are Michael Billig's book on Jewish rockers and Reyes and Waldman on Chicano rock musicians.

\section{Communications and media studies}

Not surprisingly, there is a substantial body of work from the field of communications and media studies. Influenced by McLuhan, early works include Robert Pielke's You Say You Want a Revolution (1986) and Jim Curtis' Rock Eras. In 1991, R. Serge Denisoff, and William Romanowski wrote a survey of the history of rock music in motion pictures. A non-theoretical approach to MTV was written in 1996 by Jack Banks. Michael Keith's 1997 book on the underground radio of the counterculture effectively integrates radio history into the broader historical perspective. Noteworthy is the more recent overview on the evolution of rock criticism by Lindberg et al., Rock Criticism from the Beginning (2005). 
Collection Building 27:1, 2008 (Emerald). Accepted, to be published Jan. 25, 2008.

\section{Political science}

R. Serge Denisoff's 1983 Sing a Song of Social Significance and John Orman's The Politics of Rock Music (1984) are early American considerations of the political aspects of popular music. British scholar John Street's Rebel Rock_and his 1997 Politics and Popular Culture complicate the discourse and consider the politics of popular music.

\section{Literary approaches}

Two early literary works on rock are influenced by Nietzschian Romanticism. Robert Pattison's 1987 The Triumph of Vulgarity : Rock Music in the Mirror of Romanticism makes a plausible argument that rock music is a contemporary manifestation of late eighteenth and nineteenth century Romanticism. Literary scholar Wallace Fowlie connects Jim Morrison to Rimbaud in his 1994 monograph. More recently, Larry David Smith has written a few books on popular music including one on Dylan, Springsteen and the American song that utilizes auteur theory. Lastly Steven Hamelman's 2004 But Is It Garbage? brings a traditional literary approach to his analysis of rock and the "trash trope."

\section{Art history, aesthetics, and philosophy.}

An early work on rock by a philosopher is James Harris's analysis of the philosophical themes of classic rock, Philosophy at 33 1/3 rpm (1993). Theodore Gracyk, however, uses the methodology of philosophy in a more interpretative and complex manner. His 1996 Rhythm and Noise is highly ambitious and explores the aesthetics of rock. Gracyk considers the tension between authenticity and insincerity, art and the commercial, to be at the heart of rock's power. Between Montmartre and the Mudd Club by Bernard Gendron (2002) questions the idea that rock shattered the divide between high and low culture. This book is a unique and important study that connects art history to rock history. Also published in 2002 is Bill Martin's interesting study of avant-rock. He traces avant rock from the late 1960s creations of Yoko Ono and the Velvet Underground to current performers including Sonic Youth. Lastly, the connection between the transcendent and popular music is explored in a 2005 book by Bill Friskics-Warren, I'll Take You There.

\section{Sociology}

A substantial number of academic authors on rock are sociologists or have sociological training and sociology and cultural studies have excellent synergy. The two general works by sociologists discussed are by Peter Wicke and Keith Negus. Wicke is a German scholar. His 1990 Rock Music : Culture, Aesthetics, and Sociology is informed by cultural studies. A chapter entitled, "The Ideology of rock", represents a relatively early effort to 
Collection Building 27:1, 2008 (Emerald). Accepted, to be published Jan. 25, 2008.

probe how the idea of rock as revolutionary grew out of contradictory late 1960s ideas about the relationship between aesthetic and personal change and social change. Keith Negus's thinking is highly original and he will be discussed in this article's conclusions. Negus, a sociologist and former musician, looks at the cultural impact of the music industry in his second book, the 1999 Music Genres and Corporate Cultures. The focus of the book is how genre in popular music, often developed as a marketing tool, influences musicians, listeners, and fan subcultures. Negus specifically considers how industry expectations affect musician creativity.

\section{Business and economics}

The primary academic author on the business aspects of popular music is David Sanjek. His 1991 American Popular Music Business in the 20th Century is an updated version of earlier work. Revised by his son Russell, major themes include technology and the dissemination of popular music, the consolidation of the musical marketplace into increasingly fewer corporations, and the diversification of genres of popular music. The first economist to write a full-length monograph on rock is Wilfred Dolfsma. His 2004 Institutional Economics and the Formation of Preferences : The Advent of Pop Music examines why rock became so popular in the 1950s and 1960s. Dolfsma notes that economics is informed by sociology and psychology. His conclusion is that value is socially constructed.

\section{Overview and emerging work}

If one is interested in a gesamtwerk or an overview of all rock theories, an excellent choice is Keith Negus's 1996 Popular Music in Theory : An Introduction. Negus believes that theory informs how listeners and audiences actively and generatively interpret and respond to popular music. Providing a sophisticated and exhaustive overview, Negus outlines, responds to and comments on contemporary academic writing on popular music. Rene Kolloge's 1999 The Times They Are A-Changin' : The Evolution of Rock Music and Youth Cultures is another good overview. The first half of the book covers all rock theory and then goes on to examine rock from the mid 1950s to the late 1960s because the core ideologies, styles and genres of rock, which live on to this day, originated during this period.

Three books that are excellent representations of rock scholarship at its most exciting are by Neil Nehring, Steve Waksman, and Theodore Gracyk. All three authors deeply understand the academic rock discourse and their work represents significantly original thinking as well as creative use of methodology. Neil Nehring's Popular Music, Gender, and Postmodernism : Anger is an Energy (1997) examines how feelings, considered feminine and irrational, are culturally dangerous. Particularly threatening is anger, the root of all radical resistance. Many scholars and critics are dismissive about anger in popular music. Nehring, influenced by feminist theory, seeks to reclaim anger in music and debunk postmodern cynicism and apathy on both the Left and Right ends of 
Collection Building 27:1, 2008 (Emerald). Accepted, to be published Jan. 25, 2008.

the political spectrum. Nehring says many interesting things about rock and gender, repositioning the complex debate on this topic.

The first academic book on the electric guitar was Walser's Running with the Devil. Its successor is Steven Waksman's excellent Instruments of Desire : The Electric Guitar and the Shaping of Musical Experience (1999). Waksman is an Americanist and he utilizes all possibly theoretical threads including gender, ethnicity, whiteness, and racial studies. Waksman's thesis advisor was Americanist David Roediger. The body and desire is a theme throughout the book. The chapter on Jimi Hendrix and blackness brilliantly considers why the black community rejected Hendrix. A chapter on intense noise and revolution uses the theories of Jacques Attali to examine the under-appreciated MC5. Waksman also provides a fresh discussion on the gender and sexual contradictions of heavy metal.

Lastly, Theodore Gracyk's 2001 I Wanna Be Me : Rock Music and the Politics of Identity challenges the identity politics of cultural studies scholars who view rock music as sexist, homophobic, racist, and otherwise an instrument of hegemony. In this challenging book, the author probes two major themes in the theoretical and scholarly discussion of rock music: authenticity and appropriation. Rock authenticity is related to the formation of culturally challenging personal/political identities. The author follows with a consideration of the cultural politics of appropriation of musical styles and content. Lastly, Gracyk considers how rock listeners, in their engagement with rock, respond differently to crossing over the boundaries of social class, race, gender, and sexuality.

\section{Conclusion: Current discourse overview and the authenticity debate}

A good place to conclude is with two books that focus on a core issue in the rock discourse: the idea of rock authenticity. Many of the books discussed in this bibliographic essay touch on rock authenticity either implicitly or explicitly. Steve Jones, a professor of communications, sees a connection between authenticity and technology in his 1992 Rock Formation : Music, Technology, and Mass Communication. He explores how music production can heavily influence the perception of the authenticity of a recording. How much artistic control over production do most musicians truly have? Written in the heyday of grunge, the author examines how producers deliberately make recordings sound more crude and raw in order to suggest greater authenticity and excitement. Jones ultimately concludes that authenticity in rock is immaterial because of the false presumption that there is such a thing as musical (and cultural) purity.

Kevin Dettmar's 2006 Is Rock Dead? links authenticity to the so-called death of rock. He examines the rock discourse and looks at academic writing but chiefly focuses on mainstream media including rock music itself. The rhetoric of a musical style being dead, dying or resurrected is not unique to rock: Dettmar sees this trope used for classical music and jazz. In rock, it is the fetishization of authenticity that is at the root of rock's supposed demise: rock's roots were in the African-American, or in the case of Bruce Springsteen, the working-class community. If rock does not arise from its source 
Collection Building 27:1, 2008 (Emerald). Accepted, to be published Jan. 25, 2008.

community(s), it is no longer authentic, ergo it is dead. Another source of this rhetoric is the clash between believers in "classic" rock who distain all innovation as death and rock innovators. This book is a good touchstone of the state of the art.

To conclude, academic writing on rock and popular music is approached using a very wide variety of methodologies and disciplines. This bibliographic essay identifies and critiques many key works and connects them in order to bring out major themes and trends in the evolution of the scholarly rock discourse.

A highly abbreviated version of this essay was presented at the 2007 Popular Culture Association national conference in Boston, MA.

\section{References}

Arnett, J.J. (1996), Metalheads : Heavy Metal Music and Adolescent Alienation, Westview Press, Boulder, Colo.

Auslander, P. (2006), Performing Glam Rock : Gender and Theatricality in Popular Music, University of Michigan Press, Ann Arbor, Mich.

Banks, J. (1996), Monopoly Television : MTV's Quest to Control the Music, Westview Press, Boulder, CO.

Belz, C. (1969), The Story of Rock, Oxford University Press, New York.

Bennett, H.S. (1980), On Becoming a Rock Musician, University of Massachusetts Press, Amherst.

Bennett, A. (2002), "Researching youth culture and popular music: a methodological critique", The British journal of sociology, Vol. 53 No. 3, p. 451-466.

Berger, H.M. (1999), Metal, Rock, and Jazz : Perception and the Phenomenology of Musical Experience, University Press of New England, Hanover, NH.

Bertrand, M.T. (2000), Race, Rock, and Elvis, University of Illinois Press, Urbana.

Billig, M. (2001), Rock 'n' Roll Jews, Syracuse University Press, Syracuse, N.Y.

Bowden, B. (1982), Performed Literature : Words and Music by Bob Dylan, Indiana University Press, Bloomington.

Burns, L. \& Lafrance, M. (2002), Disruptive Divas : Feminism, Identity \& Popular Music, Routledge, New York. 
Collection Building 27:1, 2008 (Emerald). Accepted, to be published Jan. 25, 2008.

Cagle, V.M. (1995), Reconstructing pop/subculture : Art, Rock, and Andy Warhol, Sage Publications, Thousand Oaks, Calif.

Carson, M.J., Lewis, T. \& Shaw, S.M. (2004), Girls Rock! : Fifty Years of Women Making Music, University Press of Kentucky, Lexington, Ky.

Cavicchi, D. (1998), Tramps Like Us : Music \& Meaning among Springsteen Fans, Oxford University Press, New York.

Covach, J. 1997, "We won't get fooled again : Rock music and musical analysis", in L. Siegel, D. Schwarz \& A. Kassabian (Eds.), Keeping Score : Music, Disciplinarity, Culture University Press of Virginia, Charlottesville, pp. 75.

Cullen, J. (1997), Born in the U.S.A. : Bruce Springsteen and the American Tradition, 1st ed., Harper Collins, New York.

Curtis, J. (1987), Rock Eras : Interpretations of Music and Society, 1954-1984, Bowling Green State University Popular Press, Bowling Green, Ohio.

Denisoff, R.S. (1983), Sing a Song of Social Significance, 2nd ed., Bowling Green State University Popular Press, Bowling Green, Ohio.

Denisoff, R.S. \& Plasketes, G. (1995), True Disbelievers : The Elvis Contagion, Transaction Publishers, New Brunswick, N.J.

Denisoff, R.S. \& Romanowski, W.D. (1991), Risky Business : Rock in Film, Transaction Publishers, New Brunswick U.S.A.

Dettmar, K.J.H. (2005), Is Rock Dead? Routledge, New York ; London.

Dolfsma, W. (2004), Institutional Economics and the Formation of Preferences: The Advent of Pop Music, Edward Elgar Publishing, Northampton, Mass.

Doll, S. (1998), Understanding Elvis : Southern Roots VS. Star Image, Garland, New York.

Doss, E.L. (1999), Elvis Culture : Fans, Faith, \& Image, University Press of Kansas, Lawrence, Kan.

Echard, W. (2005), Neil Young and the Poetics of Energy, Indiana University Press, Bloomington.

Elliott, A. (1999), The Mourning of John Lennon, University of California Press, Berkeley. 
Collection Building 27:1, 2008 (Emerald). Accepted, to be published Jan. 25, 2008.

Faith, K. (1997), Madonna, Bawdy \& Soul, University of Toronto Press, Toronto ; Buffalo.

Fast, S. (2001), In the Houses of the Holy : Led Zeppelin and the Power of Rock Music, Oxford University Press, Oxford ; New York.

Filene, B. (2000), Romancing the Folk: Public Memory \& American Roots Music, University of North Carolina Press, Chapel Hill.

Fowlie, W. (1994), Rimbaud and Jim Morrison : The Rebel as Poet, Duke University Press, Durham.

Friskics-Warren, B. (2005), I'Ll Take You there : Pop Music and the Urge for Transcendence, Continuum, New York.

Frith, S. (1988), Music for Pleasure : Essays in the Sociology of Pop, Routledge, New York.

Frith, S. (1996), Performing Rites : On the Value of Popular Music, Harvard University Press, Cambridge, Mass.

Frith, S. \& Goodwin, A. (1990), On Record : Rock, Pop, and the Written Word, 1st ed., Pantheon Books, New York.

Garman, B.K. (2000), A Race of Singers : Whitman's Working-Class Hero from Guthrie to Springsteen, University of North Carolina Press, Chapel Hill.

Gendron, B. (2002), Between Montmartre and the Mudd Club : Popular Music and the Avant-Garde, University of Chicago Press, Chicago.

Gillett, C. (1970), The Sound of the City: The Rise of Rock and Roll, Outerbridge \& Dienstfrey, distributed by E.P. Dutton, New York.

Goodwin, A. (1992), Dancing in the Distraction Factory : Music Television and Popular Culture, University of Minnesota Press, Minneapolis.

Gracyk, T. (2001), I Wanna be Me : Rock Music and the Politics of Identity, Temple University Press, Philadelphia.

Gracyk, T. (1996), Rhythm and Noise: An Aesthetics of Rock, Duke University Press, Durham, NC.

Grenier, L., Kassabian, A., Brackett, D. \& Straw, W. (1999), "Roundtable: The Future of Popular Music Studies", Journal of Popular Music Studies, Vol. 11-12 No. 1, p. 151166. 
Collection Building 27:1, 2008 (Emerald). Accepted, to be published Jan. 25, 2008.

Guilbert, G. (2002), Madonna as Postmodern Myth : How One Star's Self-Construction Rewrites Sex, Gender, Hollywood, and the American Dream, McFarland \& Co., Jefferson, N.C.

Hamelman, S.L. (2004), But is it Garbage? : On Rock and Trash, University of Georgia Press, Athens.

Harrington, C.L. \& Bielby, D.D. 2001, "Constructing the popular: Cultural production and consumption", in C.L. Harrington \& D.D. Bielby (Eds.), Popular Culture : Production and Consumption Blackwell Publishers, Malden, Mass., pp. 1-15.

Harris, J.F. (1993), Philosophy at 33 1/3 Rpm : Themes of Classic Rock Music, Open Court, Chicago, Ill.

Herdman, J. (1982), Voice without Restraint : A Study of Bob Dylan's Lyrics and their Background, Delilah Books : Distributed by G.P. Putnam's Sons, New York.

Hicks, M. (1999), Sixties Rock : Garage, Psychedelic, and Other Satisfactions, University of Illinois Press, Urbana.

Howard, J.R. \& Streck, J.M. (1999), Apostles of Rock: The Splintered World of Contemporary Christian Music, University Press of Kentucky, Lexington.

Jones, S. (1992), Rock Formation : Music, Technology, and Mass Communication, Sage, Newbury Park, Calif.

Kaplan, E.A. (1987), Rocking Around the Clock : Music Television, Postmodernism, and Consumer Culture, Methuen, New York.

Kearney, M.C. (2006), Girls make Media, 1st ed., Routledge, New York.

Keith, M.C. (1997), Voices in the Purple Haze : Underground Radio and the Sixties, Praeger, Westport, Conn.

Kolloge, R. (1999), The Times they are a-Changin' : The Evolution of Rock Music and Youth Cultures, Peter Lang, Frankfurt am Main ; New York.

Kruse, R.J. (2005), A Cultural Geography of the Beatles : Representing Landscapes as Musical Texts (Strawberry Fields, Abbey Road, and Penny Lane), E. Mellen Press, Lewiston, N.Y.

Laing, D. (1985), One Chord Wonders : Power and Meaning in Punk Rock, Open University Press, Milton Keynes, England ; Philadelphia.

Laird, T.E.W. (2005), Louisiana Hayride : Radio and Roots Music Along the Red River, Oxford University Press, Oxford ; New York. 
Collection Building 27:1, 2008 (Emerald). Accepted, to be published Jan. 25, 2008.

Lehman, P. (2003), Roy Orbison : The Invention of an Alternative Rock Masculinity, Temple University Press, Philadelphia.

Lewis, L.A. (1990), Gender Politics and MTV : Voicing the Difference, Temple University Press, Philadelphia.

Lindberg, Ulf et al. (2005), Rock Criticism from the Beginning : Amusers, Bruisers, and Cool-Headed Cruisers, Peter Lang, New York.

London, H.I. (1984), Closing the Circle : A Cultural History of the Rock Revolution, Nelson-Hall, Chicago.

Mahon, M. (2004), Right to Rock: The Black Rock Coalition and the Cultural Politics of Race, Duke University Press, Durham.

Malott, C. \& Peña, M. (2004), Punk Rockers' Revolution : A Pedagogy of Race, Class, and Gender, Peter Lang, New York.

Marcus, G. (1991), Dead Elvis : A Chronicle of a Cultural Obsession, 1st ed., Doubleday, New York.

Marcus, G. (1997), Invisible Republic : Bob Dylan's Basement Tapes, Picador, London.

Marcus, G. (1975), Mystery Train : Images of America in Rock ' $n$ ' Roll Music, 1st ed., E.P. Dutton, New York.

Marcus, G. (2005), Once upon a Time : Bob Dylan's Like a Rolling Stone, 1st ed., PublicAffairs, New York.

Marling, K.A. (1996), Graceland : Going Home with Elvis, Harvard University Press, Cambridge, Mass.

Martin, B. (2002), Avant Rock : Experimental Music from the Beatles to Björk, Open Court, Chicago.

Mellers, W.H. (1986), Angels of the Night : Popular Female Singers of our Time, B. Blackwell, New York.

Mellers, W.H. (1985), A Darker Shade of Pale : A Backdrop to Bob Dylan, Oxford University Press, New York.

Middleton, R. (1990), Studying Popular Music, Open University Press, Milton Keynes England ; Philadelphia. 
Collection Building 27:1, 2008 (Emerald). Accepted, to be published Jan. 25, 2008.

Miklitsch, R. 1998, "The case of madonna studies", in From Hegel to Madonna :

Towards a General Economy of "Commodity Fetishism" State University of New York Press, Albany, pp. 224.

Mowitt, J. (2002), Percussion : Drumming, Beating, Striking, Duke University Press, Durham.

Negus, K. (1999), Music Genres and Corporate Cultures, Routledge, London ; New York.

Negus, K. (1997), Popular Music in Theory : An Introduction, 1st U.S. ed., University Press of New England, Hanover, NH.

Nehring, N. (1997), Popular Music, Gender, and Postmodernism : Anger is an Energy, Sage Publications, Thousand Oaks, Calif.

Orman, J.M. (1984), The Politics of Rock Music, Nelson-Hall, Chicago.

Pattison, R. (1987), The Triumph of Vulgarity : Rock Music in the Mirror of Romanticism, Oxford University Press, New York.

Pielke, R.G. (1986), You Say You Want a Revolution : Rock Music in American Culture, Nelson-Hall, Chicago.

Plasketes, G. (1997), Images of Elvis Presley in American Culture, 1977-1997 : The Mystery Terrain, Haworth Press, New York.

Pratt, R. (1990), Rhythm and Resistance : Explorations in the Political Uses of Popular Music, Praeger, New York.

Radway, J.A. (1991), Reading the Romance : Women, Patriarchy, and Popular Literature, University of North Carolina Press, Chapel Hill.

Reyes, D. \& Waldman, T. (1998), Land of a Thousand Dances : Chicano Rock ' $n$ ' Roll from Southern California, 1st ed., University of New Mexico Press, Albuquerque.

Reynolds, S. \& Press, J. (1995), The Sex Revolts : Gender, Rebellion, and Rock 'n' Roll, Harvard University Press, Cambridge, Mass.

Rhodes, L. (2005), Electric Ladyland : Women and Rock Culture, University of Pennsylvania Press, Philadelphia.

Ricks, C.B. (2004), Dylan's Visions of Sin, Ecco, New York.

Rodman, G.B. (1996), Elvis After Elvis : The Posthumous Career of a Living Legend, Routledge, London; New York. 
Collection Building 27:1, 2008 (Emerald). Accepted, to be published Jan. 25, 2008.

Sadie, S. \& Tyrrell, J. (2001), The New Grove Dictionary of Music and Musicians, 2nd ed., Grove, New York.

Sanjek, R. \& Sanjek, D. (1991), American Popular Music Business in the 20th Century, Oxford University Press, New York.

Scheurer, T.E. (1991), Born in the U.S.A. : The Myth of America in Popular Music from Colonial Times to the Present, University Press of Mississippi, Jackson.

Schippers, M. (2002), Rockin' Out of the Box : Gender Maneuvering in Alternative Hard Rock, Rutgers University Press, New Brunswick, N.J.

Schwarz, D. (1997), Listening Subjects : Music, Psychoanalysis, Culture, Duke University Press, Durham.

Shank, B. (1994), Dissonant Identities : The Rock ' $n$ ' Roll Scene in Austin, Texas, University Press of New England, Hanover, NH.

Shepherd, J. (1991), Music as Social Text, Polity Press, Cambridge, UK.

Shuker, R. (2001), Understanding Popular Music, 2nd ed., Routledge, London ; New York.

Smith, L.D. (2002), Bob Dylan, Bruce Springsteen, and American Song, Praeger, Westport, Conn.

Street, J. (1997), Politics and Popular Culture, Temple University Press, Philadelphia.

Street, J. (1986), Rebel Rock: The Politics of Popular Music, Blackwell, Oxford, OX, UK ; New York, NY, USA.

Sullivan, H.W. (1995), The Beatles with Lacan : Rock ' $n$ ' Roll as Requiem for the Modern Age, P. Lang, New York.

Sylvan, R. (2002), Traces of the Spirit : The Religious Dimensions of Popular Music, New York University Press, New York.

Thompson, S. (2004), Punk Productions : Unfinished Business, State University of New York Press, Albany.

Waksman, S. (1999), Instruments of Desire: The Electric Guitar and the Shaping of Musical Experience, Harvard University Press, Cambridge, Mass.

Walser, R. (1993), Running with the Devil : Power, Gender, and Madness in Heavy Metal Music, University Press of New England, Hanover, NH. 
Collection Building 27:1, 2008 (Emerald). Accepted, to be published Jan. 25, 2008.

Watson, B. (1995), Frank Zappa : The Negative Dialectics of Poodle Play, 1st U.S. ed., St. Martin's Press, New York.

Weinstein, D. (2000), Heavy Metal : The Music and its Culture, Rev. , 1st Da Capo Press ed., Da Capo Press, New York.

White, T. (1994), The Nearest Faraway Place : Brian Wilson, the Beach Boys, and the Southern California Experience, 1st ed., H. Holt, New York.

Whiteley, S. (2000), Women and Popular Music : Sexuality, Identity, and Subjectivity, Routledge, London; New York.

Wicke, P. (1990), Rock Music : Culture, Aesthetics, and Sociology, Cambridge University Press, Cambridge ; New York.

Wiener, J. (1991), Come Together : John Lennon in His Time, Illini books ed., University of Illinois Press, Urbana.

Wiener, J. (1999), Gimme some Truth : The John Lennon FBI Files, University of California Press, Berkeley Calif.

Young, T.H. (1989), Break all Rules! : Punk Rock and the Making of a Style, UMI Research Press, Ann Arbor, Mich. 